\title{
Effect of consumption of I, Se, S and nanoaquacitrates on hematological and biochemical parameters of the organism of rabbits
}

\author{
O. V. Boiko*, O. F. Honchar*, Y. V. Lesyk**, I. I. Kovalchuk***, B. V. Gutyj***, A. Z. Dychok-Niedzielska** \\ *Cherkassy Experimental Station of Bioresources National Academy of Agricultural Sciences of Ukraine, Cherkassy, Ukraine \\ **Institute of Animal Biology of NAAS, Lviv, Ukraine \\ ***Stepan Gzhytskyi National University of Veterinary Medicine and Biotechnologies Lviv, Ukraine
}

Article info

Received 23.04.2021

Received in revised form

19.05.2021

Accepted 20.05.2021

Cherkassy Experimental Station of Bioresources National Academy of

Agricultural Sciences of Ukraine,

Pasterivska st., 76

Cherkassy, 18036, Ukraine

Tel.: +38-047-231-40-52.

E-mail:bioresurs.ck@ukr.net

Institute of Animal Biology of NAAS, V. Stus st., 38, Lviv, 79034, Ukraine.

$\mathrm{Tel} \cdot \mathbf{3}+38-068-503-46-25$

E-mail:yaroslavlesyk@

inenbiol.com.ua

Stepan Gzhytskyi National University of Veterinar

Medicine and Biotechnologies

Lviv, Pekarskast., 50

Lviv, 79010, Ukraine.

Tel.: +38-068-136-20-54

E-mail:bvh@ukr.net
Boiko, O. V., Honchar, O. F., Lesyk, Y. V., Kovalchuk, I. I., Gutyj, B. V., \& Dychok-Niedzielska, A. Z. (2021). Effect of consumption of I, Se, $S$ and nanoaquacitrates on hematological and biochemical parameters of the organism of rabbits. Regulatory Mechanisms in Biosystems, 12(2), 335-340. doi:10.15421/022145

Using nanotechnologies to obtain compounds of mineral substances is promising because of the importance of the amount of mineral substances, but the limiting factor is particularly their bioavailability in the digestive tract. The conducted studies determined the stimulating effect of nanoaquachelates of separate biogene microelements on the course of biochemical processes of the organisms of animals, their productivity and quality of the obtained products. However, the mechanisms of impact of carboxylates of separate elements and their combinations on functioning of physiological systems of various species of animals, level of transformation of these elements into the products and their biological value remain unstudied. Therefore, the objectives of the study were changes in hematological biochemical and productive parameters of the organisms of rabbits consuming I, Se, S, the impacts of these elements on their organism from the 53 to 85th days of life. Studies were performed on young Termonde rabbits. Animals of experimental groups I, II, III, and IV were fed with feeds of the diet of the control group for $24 \mathrm{~h}$ with water containing solution of I, Se, S calculated respectively as $2.5,5.0,10.0$ and $20.0 \mu \mathrm{g}$ of $\mathrm{I} / \mathrm{L}$ of water. The experiment lasted 45 days, including a 12 day preparation period and 33 day experimental. On the 53rd day of life of animals in the preparation period, and 68th and 85th days of life in the experimental periods (15th and 33rd days of watering with supplements), we collected samples of blood from the marginal ear vein of 6 animals ( 3 males and 3 females) of the group for hematological and biochemical studies. We determined that watering with the solution of microelements I, Se, S led to changes in the overall amount of white blood cells, making it $17.1 \%$ lower in the blood of animals of the experimental group II, $26.2 \%$ higher in group III on the 15th day, and $12.0 \%$ higher in group IV on the 31st day of the experiment compared with the control. Absolute amounts of lymphocytes, monocytes and granulocytes by the periods of the study were observed to have no significant changes throughout the study, though their parameters were within the physiological values compared with the control. The amount of red blood cells in the blood of rabbits of experimental groups I, II and III was higher respectively by $8.1 \%, 5.7 \%$ and $12.0 \%$ at the first stage of the study and $18.1 \%, 13.3 \%, 24.5 \%$ and $24.9 \%$ higher in animals of experimental groups I, II; III and IV at the final stage of the study compared with the control group. Hemoglobin concentration in blood of rabbits of experimental groups II and III during the study was significantly higher. Hematocrit value in blood of rabbits of experimental groups I-III was significantly higher on the 33rd day of the experiment compared with the control. Consumption of solution of microelements in the amount of $10.0 \mu \mathrm{g}$ of I/L by the animals of experimental group III led to $15.1 \%$ higher content of total protein in the blood on the 33rd day of the study compared with the control group of animals. The level of creatinine was no higher than the physiological parameters and was $9.2 \%, 15.0 \%$ and $15.4 \%$ higher in the blood of rabbits of experimental groups II, III, IV on the 33rd day of the experiment compared with the control group. No significant changes in the content of triacylglycerols in the blood of rabbits of the experimental groups were seen throughout the study. However, the content of cholesterol in the blood of rabbits of experimental groups III and IV was significantly higher at the first stage compared with the control group. Further, it is practical to study physiologically substantiated amounts of solution of microelements I, Se, S in the diet of mother rabbits to determine their effect on their ability to become pregnant, reproductive function, milk production and survival of offspring.

Keywords: nanotechnologies; mineral substances; formed elements of blood; enzymes; protein.

\section{Introduction}

In the conditions of industrial rabbit breeding using genotypes of fast growing young rabbits, the requirements for provision of genetic potential of productivity and optimization of diets of animals are becoming more demanding (Sheiha et al., 2020). Among nutrients, an important role in the diet of rabbits is played by mineral elements that have no nutritive value but which activate enzymic systems in the organism of animals (AbdelWareth \& Metwally, 2020; Lesyk et al., 2020). Mineral substances in physiological amounts in the organism affect the functions of hematopoiesis, endocrinous glands, resistance of the organism, microflora of the digestive tract, which is extremely important for young rabbits because their digestive tract completes its development by the third month of life, regulate metabolism, take part in biosynthesis of protein, penetrability of cellular membranes. Enrichment of fodders with biogenic-active components that contain no nutrients, the mineral compounds being co-factors of enzymes and diet constituents without nutritive value, may help to balance the general nutrient profile in the diet and add nutrients that had not been digested in the process of biotransformation, and therefore correct or prevent their insufficient ingression and disadvantages related to them (Dwyer et al., 2015; Shulman et al., 2017; Zazharska et al., 2018).

Therefore, providing rabbits of contemporary industrial breeds with sufficient amount of mineral compounds in their diet is an extremely important factor (Abdel-Wareth et al., 2018). During the past decade, 
nanotechnologies using microelements and especially ultramicroelements have been actively developing (Shi et al., 2011). Nanotechnologies are a rapidly developing sphere that develops materials of new sizes, new properties and broad spectrum of use. Sizes of nanoparticles used for nanotechnologies range 1 to $100 \mathrm{~nm}$. According to the Recommendations for Identification of Nanomaterial adopted by the European Commision, the term "nanomaterial" means "natural, incidental or manufactured material containing particles, in an unbound state or as an aggregate or as an agglomerate and where, for $50 \%$ or more of the particles in the number size distribution, one or more external dimensions is in the size range $1 \mathrm{~nm}-$ $100 \mathrm{~nm}$ " (European Commission). Therefore, application of the principles of nanotechnologies may be considered an effective tool for modifying parameters of bioactive substances. Modification of the properties comprises using nanosystems/nanoformulas, increasing bioavailability of biologically active substances, and moreover, lower but more efficient amounts of a substance used reduces dose-dependent toxicity and various side effects of their use.

Use of nanotechnologies to obtain compounds of mineral substances is promising because the amount of mineral substances is an important but a limiting factor of their bioavailability in the digestive tract (Abd-Allah \& Hashem, 2015). The literature sources provide examples of complete quantitative provision with complex of mineral elements, but the end result of their participation in metabolism is partly due to poor bioavailability for the cell and participation of biochemical reactions in catalysis (Reda et al., 2020). This was confirmed by the studies where nanoaquachelates of separate biogenic microelements had positively stimulated the biochemical processes in the organisms of animals, their productivity and quality of the obtained products (Abouelezz et al., 2019). The main function of nanocompounds is support of the normal functioning of the organism through bioavailability of substances of the diet which cannot be digested completely. These studies are some of the first of their kind conducted in Ukraine and around the globe, which are confirmed by patents and some publications. Development of methods of synthesis and studying properties of nanoparticles, due to their specific physical taxichemical properties, opens new perspectives of fundamental understanding of the action of nanomaterials towards the condition and functional activity of cells, organisms, as well as their practical and effective application (Swelum et al., 2021). The amount of experimental studies on obtaining and biological action of nanoparticles of metals increases annually, indicating promising opportunities of using nanoparticles in technologies of construction of highly effective medical drugs (Lesyk et al., 2020). However, it is impossible to imagine the solution to this problem without the use of contemporary achievements of nanotechnologies, molecular biology and veterinary medicine. Nonetheless, the mechanism of influence of carboxylates of separate elements and their combinations on functioning of physiological systems of various species of animals, level of transformation of those elements in products and its biological value still remain to be studied. Therefore, the objectives of our study were changes in the hematological biochemical and productive parameters of the organisms of rabbits in the conditions of effect of different amounts of $\mathrm{I}, \mathrm{Se}, \mathrm{S}$ on their organism in the period from 53rd to 85th day of life.

\section{Materials and methods}

The studies were performed on young Termonde rabbits in the vivarium of the Institute of Animal Biology of the Ukrainian National Academy of Sciences. All the experimental interventions and slaughter of the animals were performed following the requirements of the European Convention for the Protection of Vertebrate Animals used for Experimental and other Scientific Purposes (Strasburg, 1985) and the Resolution of the First National Congress of Bioethics (Kyiv, 2001).

For the studies, we had selected rabbits aged 41 days and weighing $1.2-1.4 \mathrm{~kg}$ using the analogue principle, and divided them into five groups (control and four experimental), with 6 animals ( 3 males and 3 females) in each. The animals were kept in $50 \times 120 \times 30 \mathrm{~cm}$ grid cages in rooms with regulated microclimate and light, in accordance with the modern veterinary-sanitary norms. Rabbits of the control group were given unlimited balanced granulated compound fodder, and had free access to water. Animals of experimental groups I, II, III and IV were fed with fodders of the diet of the control group plus solution of $\mathrm{I}, \mathrm{Se}, \mathrm{S}$ in the dosages of respectively $2.5,5.0,10.0$ and $20.0 \mu \mathrm{g} \mathrm{I} / \mathrm{L}$ of water per day. The experiment lasted for 45 days, including 12 days preparation period, and the experimental period of 33 days. On the 53 rd day during the preparation, and 68th and 85th days of life of the rabbits (15th and 33rd days of watering with the supplements), we collected blood samples from 6 animals ( 3 males and 3 females) for hematologic and biochemical studies.

Blood for hematological study was taken in test tubes that contained dicatylen salt of ethylenediaminetetraacetic acid $\left(\right.$ EDTA $\left.-\mathrm{K}_{2}^{+}\right)$, which served as an anticoagulant, for biochemical studies, we used $1 \%$ heparin as anticoagulant. In the blood, we determined total number of red blood cells (RBC), concentration of hemoglobin (HGB), hematocrit (HCT) and erythrocyte indices (mean corpuscular volume (MCV), mean corpuscular hemoglobin $(\mathrm{MCH})$, mean corpuscular hemoglobin concentration (MCHC), red cell distribution width (RDW)), number of white blood cells (WBC) and their forms - lymphocytes (LYM), monocytes (MON), granulocytes (GRA) and amount of platelets (PLT) and platelet indexes (mean platelet volume (MPV), and plateletcrit (PCT), and platelet distribution width (PDW)) and hematology analyzer Mythic 18. The study of biochemical parameters: activity of alkaline phosphatase. Cholesterol, triacylglycerols, total calcium and non-organic phosphorus, total protein, activity of alanine- (ALT) and aspartate aminotransferases (AST) in blood plasma of rabbits were examined using biochemical analyzer Humalazer2000 and standard kit manufactured by LACHEMA (Czech Republic (Vlislo, 2012).

Mathematical analysis of the research results was developed statistically using software pack Statistica 7.0 (StatSoft, Tulsa, USA). Differences between the values in the control and the experimental groups were determined using ANOVA, where the differences were considered significant at $\mathrm{P}<0.05$ (taking into account Bonferroni correction).

\section{Results}

The studies revealed that watering with citrate solution of microelements I, Se, S led to changes in hematological parameters in the blood of rabbits (Table 1). Therefore, the total amount of white blood cells in the blood of animals of experimental group II was $17.1 \%$ lower, and in group III exceeded $26.2 \%$ on the 15 th day of the study compared with the control group. It has to be noted that watering great amounts of solution of microelements in the blood of rabbits of group IV was followed by $12.0 \%$ increase in the amount of white blood cells on the 31st day of the study compared with the control. Analysis of absolute amounts of lymphocytes, monocytes and granulocytes according to the periods of the study found no significant changes throughout the study, though their parameters were within physiological values compared with the control.

Somewhat different results were obtained for the parameters of the red blood of the rabbits. In particular, the number of red blood cells in the blood of rabbits of experimental groups I, II and III was higher by $8.1 \%$, $5.7 \%$ and $12.0 \%(\mathrm{P}<0.05)$ at the first stage of the study and higher in animals of experimental groups I, II; III and IV respectively by $18.1 \%$ $(\mathrm{P}<0.05), 13.3 \%(\mathrm{P}<0.05), 24.5 \%$ and $24.9 \%(\mathrm{P}<0.001)$ at the final stage of the study compared with the control group of animals (Table 2).

Concentration of hemoglobin in the blood of rabbits of experimental groups II and III experimental groups throughout the study was significantly higher $(\mathrm{P}<0.05)$, and also higher levels of this parameter were seen in animals of group I on the 33rd day of the study compared with the control. The studies revealed changes in hematocrit values in the blood of rabbits at the final stage of the study, being significantly higher than in the blood of animals of experimental groups I-III with significant differences $(\mathrm{P}<0.001-0.05)$ against the control. Changes in erythrocyte indices of the red blood of rabbits were within the physiological values and were not significant compared with the control, except mean concentration of hemoglobin on the 15 th day.

Watering solution of citrates of microelements caused no significant differences between the control and experimental groups (Table 4). However, the determined tendencies in the content of the examined parameters may indicate a positive impact of the applied amounts of compounds of microelements on the organisms of young rabbits. Despite the variability in the hematological parameters of the organisms of rabbits of modern 
industrial breeds depending on breed and individual peculiarities, indices of red blood cells, white blood cells and platelets were within physiological parameters, and the use of various amounts of solution of citrate microelements demonstrated dose-dependent impact on the functioning of the hematopoietic system of the rabbits in a critical period of ontogenesis.

Table 1

Content of white blood cells and leukocytic indices in blood of rabbits during watering with different amounts of $\mathrm{I}, \mathrm{Se}, \mathrm{S}(\mathrm{x} \pm \mathrm{SE}, \mathrm{n}=6)$

\begin{tabular}{|c|c|c|c|c|}
\hline \multirow{3}{*}{ Parameters } & \multirow{3}{*}{$\begin{array}{c}\text { Group } \\
\text { of } \\
\text { animal }\end{array}$} & \multicolumn{3}{|c|}{ Periods of study } \\
\hline & & \multirow{2}{*}{$\begin{array}{l}\text { preparation, } \\
53 \text { day of life }\end{array}$} & \multicolumn{2}{|c|}{$\begin{array}{c}\text { experimental } \\
\text { (day of life/day of the study) }\end{array}$} \\
\hline & & & $68 / 15$ & $85 / 33$ \\
\hline \multirow{5}{*}{$\mathrm{WBC}, 10^{9} / \mathrm{L}$} & $\mathrm{C}$ & $9.47 \pm 0.90$ & $10.37 \pm 1.04$ & $8.12 \pm 0.36$ \\
\hline & I & $7.33 \pm 1.19$ & $9.54 \pm 1.53$ & $10.22 \pm 1.16$ \\
\hline & II & $7.35 \pm 0.76$ & $8.53 \pm 0.76$ & $9.78 \pm 1.33$ \\
\hline & III & $8.27 \pm 0.35$ & $13.08 \pm 2.54$ & $8.27 \pm 0.33$ \\
\hline & IV & $9.10 \pm 1.56$ & $11.08 \pm 2.33$ & $9.10 \pm 0.28$ \\
\hline \multirow{5}{*}{$\mathrm{LYM}, 10^{9} / \mathrm{L}$} & $\mathrm{C}$ & $4.10 \pm 0.38$ & $4.25 \pm 0.34$ & $2.72 \pm 0.24$ \\
\hline & I & $2.83 \pm 0.26^{*}$ & $3.68 \pm 0.27$ & $3.45 \pm 0.43$ \\
\hline & II & $3.55 \pm 0.47$ & $3.45 \pm 0.35$ & $3.68 \pm 0.56$ \\
\hline & III & $3.20 \pm 0.18$ & $5.23 \pm 0.58$ & $3.18 \pm 0.09$ \\
\hline & IV & $4.55 \pm 0.73$ & $5.22 \pm 0.58$ & $4.75 \pm 0.25^{* * *}$ \\
\hline \multirow{5}{*}{$\mathrm{MON}, 10^{9} / \mathrm{L}$} & $\mathrm{C}$ & $1.20 \pm 0.22$ & $1.58 \pm 0.22$ & $1.27 \pm 0.29$ \\
\hline & I & $0.95 \pm 0.23$ & $1.18 \pm 0.19$ & $1.32 \pm 0.14$ \\
\hline & II & $0.93 \pm 0.08$ & $1.32 \pm 0.26$ & $1.37 \pm 0.24$ \\
\hline & III & $1.08 \pm 0.28$ & $1.80 \pm 0.43$ & $1.66 \pm 0.23$ \\
\hline & IV & $1.13 \pm 0.26$ & $1.72 \pm 0.34$ & $1.95 \pm 0.25$ \\
\hline \multirow{5}{*}{ GRA, $10^{9} / \mathrm{L}$} & $\mathrm{C}$ & $4.53 \pm 0.58$ & $4.57 \pm 0.64$ & $3.94 \pm 0.21$ \\
\hline & I & $5.15 \pm 1.78$ & $4.66 \pm 1.27$ & $3.20 \pm 0.48$ \\
\hline & II & $2.90 \pm 0.43^{*}$ & $3.77 \pm 0.43$ & $4.32 \pm 0.58$ \\
\hline & III & $5.25 \pm 1.36$ & $6.03 \pm 1.65$ & $3.80 \pm 0.32$ \\
\hline & IV & $4.45 \pm 1.27$ & $4.12 \pm 1.14$ & $6.20 \pm 0.67^{* *}$ \\
\hline
\end{tabular}

Note: statistically significant differences were taken into account compared with the control group: * $-\mathrm{P}<0.05$, ** $-\mathrm{P}<0.01$, *** $-\mathrm{P}<0.001$; the selections were compared within one line (taking into account Bonferroni correction).

Table 2

The amount of erythrocytes, concentration of hemoglobin and hematocrit values of rabbits consuming different amounts of $\mathrm{I}, \mathrm{Se}, \mathrm{S}(\mathrm{x} \pm \mathrm{SE}, \mathrm{n}=6)$

\begin{tabular}{|c|c|c|c|c|}
\hline \multirow{3}{*}{ Parameter } & \multirow{3}{*}{$\begin{array}{l}\text { Group of } \\
\text { animals }\end{array}$} & \multicolumn{3}{|c|}{ Periods of the study } \\
\hline & & \multirow{2}{*}{$\begin{array}{l}\text { preparation, } \\
\text { 53rd day of life }\end{array}$} & \multicolumn{2}{|c|}{$\begin{array}{c}\text { experimental } \\
\text { (day of life/day of the study) }\end{array}$} \\
\hline & & & $68 / 15$ & $85 / 33$ \\
\hline \multirow{5}{*}{$\begin{array}{l}\mathrm{RBC}, \\
10^{12} / \mathrm{L}\end{array}$} & $\mathrm{C}$ & $5.66 \pm 0.23$ & $5.55 \pm 0.13$ & $5.30 \pm 0.13$ \\
\hline & I & $6.03 \pm 0.32$ & $6.00 \pm 0.18$ & $6.26 \pm 0.29 *$ \\
\hline & II & $5.37 \pm 0.43$ & $5.87 \pm 0.19$ & $6.01 \pm 0.31$ \\
\hline & III & $6.15 \pm 0.24$ & $6.22 \pm 0.26^{*}$ & $6.60 \pm 0.11^{* * *}$ \\
\hline & IV & $6.25 \pm 0.21$ & $6.03 \pm 0.42$ & $6.62 \pm 0.04 * * *$ \\
\hline \multirow{5}{*}{$\mathrm{HGB}, \mathrm{g} / \mathrm{L}$} & $\mathrm{C}$ & $130.2 \pm 6.9$ & $123.3 \pm 4.3$ & $120.6 \pm 2.7$ \\
\hline & I & $133.5 \pm 7.5$ & $129.6 \pm 5.0$ & $143.6 \pm 1.4^{* * *}$ \\
\hline & II & $123.7 \pm 8.5$ & $135.8 \pm 1.8^{*}$ & $145.0 \pm 5.7^{* *}$ \\
\hline & III & $137.5 \pm 8.1$ & $135.7 \pm 1.3^{*}$ & $144.4 \pm 4.5^{* *}$ \\
\hline & IV & $142.7 \pm 5.1$ & $124.7 \pm 6.3$ & $136.7 \pm 6.2 *$ \\
\hline \multirow{5}{*}{ HCT, $\%$} & $\mathrm{C}$ & $56.4 \pm 3.3$ & $53.9 \pm 2.0$ & $52.6 \pm 1.3$ \\
\hline & I & $57.1 \pm 4.1$ & $57.5 \pm 2.2$ & $61.9 \pm 3.8^{*}$ \\
\hline & II & $57.8 \pm 1.0$ & $57.8 \pm 2.1$ & $59.8 \pm 1.9^{*}$ \\
\hline & III & $59.2 \pm 1.9$ & $54.7 \pm 1.7$ & $63.5 \pm 2.0 * *$ \\
\hline & IV & $55.1 \pm 4.3$ & $56.5 \pm 4.1$ & $58.7 \pm 2.6$ \\
\hline
\end{tabular}

Consumption of different amounts of citrates of microelements led to changes in biochemical parameters in the blood of the rabbits (Table 5). In particular, at the first and second stages of the study, ingression of supplement caused a tendency towards change in this parameter compared with the control. However, consumption of solution of microelements in the amount $10.0 \mu \mathrm{g}$ of $\mathrm{I} / \mathrm{L}$ of water by animals of the experimental group III caused $15.1 \%$ higher content of total protein in the blood on the 33rd day of the study compared with the control group of animals.

Consumption of the added mineral substances by the rabbits led to changes in the activity of enzymes of transamination and alkaline phosphatase. Activity of AST in the blood of rabbits was insignificant compared with the control group, which was characteristic for herbivorous mammals in contrast to carnivores. Activity of AST was distinct by insig- nificant changes throughout the study compared with the control. Activity of alkaline phosphatase was higher in the blood of animals of experimental groups II, III and VI respectively by $43.5,45.0$ and $27.6(\mathrm{P}<0.01-$ 0.05 ) on the 15 th day of the study in the conditions of tendential changes at the final stage of the experiment compared with the control group of animals.

\section{Table 3}

Indices of red blood cells in the blood of rabbits consuming different amounts of $\mathrm{I}, \mathrm{Se}, \mathrm{S}(\mathrm{x} \pm \mathrm{SE}, \mathrm{n}=6)$

\begin{tabular}{|c|c|c|c|c|}
\hline \multirow{3}{*}{ Parameter } & \multirow{3}{*}{$\begin{array}{l}\text { Group of } \\
\text { animals }\end{array}$} & \multicolumn{3}{|c|}{ Periods of the study } \\
\hline & & \multirow{2}{*}{$\begin{array}{l}\text { preparation, } \\
53^{\text {rd }} \text { day of life }\end{array}$} & \multicolumn{2}{|c|}{$\begin{array}{c}\text { experimental (age/period } \\
\text { of watering supplements, day) }\end{array}$} \\
\hline & & & $68 / 15$ & $85 / 33$ \\
\hline \multirow{5}{*}{$\mathrm{MCV}, \mathrm{fL}$} & $\mathrm{C}$ & $98.7 \pm 0.9$ & $96.2 \pm 0.7$ & $98.4 \pm 0.9$ \\
\hline & I & $96.7 \pm 1.2$ & $96.1 \pm 1.2$ & $94.7 \pm 2.0$ \\
\hline & II & $96.0 \pm 1.0$ & $96.8 \pm 0.9$ & $94.6 \pm 2.4$ \\
\hline & III & $97.0 \pm 0.9$ & $91.8 \pm 1.3^{*}$ & $97.1 \pm 3.1$ \\
\hline & IV & $97.5 \pm 1.6$ & $93.7 \pm 2.1$ & $88.3 \pm 0.1 * * *$ \\
\hline \multirow{5}{*}{$\mathrm{MCH}, \mathrm{pg}$} & $\mathrm{C}$ & $22.9 \pm 0.3$ & $22.2 \pm 0.4$ & $22.6 \pm 0.3$ \\
\hline & I & $22.1 \pm 0.3$ & $22.3 \pm 0.5$ & $22.2 \pm 0.3$ \\
\hline & II & $22.3 \pm 0.2$ & $22.1 \pm 0.5$ & $21.9 \pm 0.3$ \\
\hline & III & $22.8 \pm 0.3$ & $22.1 \pm 0.2$ & $22.0 \pm 0.7$ \\
\hline & IV & $22.8 \pm 0.2$ & $21.6 \pm 0.8$ & $20.5 \pm 0.1 * * *$ \\
\hline \multirow{5}{*}{$\begin{array}{l}\mathrm{MCHC}, \\
\mathrm{g} / \mathrm{L}\end{array}$} & $\mathrm{C}$ & $231.7 \pm 1.8$ & $230.8 \pm 3.6$ & $230.5 \pm 3.7$ \\
\hline & I & $228.7 \pm 2.8$ & $232.2 \pm 3.8$ & $234.0 \pm 1.7$ \\
\hline & II & $232.5 \pm 0.4$ & $227.6 \pm 3.5$ & $232.5 \pm 2.9$ \\
\hline & III & $233.7 \pm 9.9$ & $241.0 \pm 1.4^{*}$ & $228.6 \pm 1.6$ \\
\hline & IV & $222.0 \pm 8.6$ & $230.6 \pm 4.5$ & $231.5 \pm 1.1$ \\
\hline \multirow{5}{*}{ RDW, \% } & $\mathrm{C}$ & $9.7 \pm 0.4$ & $10,0 \pm 0.1$ & $10.3 \pm 0.3$ \\
\hline & I & $9.7 \pm 0.4$ & $10.9 \pm 0.4$ & $11.0 \pm 0.5$ \\
\hline & II & $10.3 \pm 0.4$ & $10.6 \pm 0.6$ & $10.4 \pm 0.6$ \\
\hline & III & $10.8 \pm 0.8$ & $11.0 \pm 0.2^{* *}$ & $11.3 \pm 0.1 *$ \\
\hline & IV & $10.3 \pm 0.4$ & $10.8 \pm 0.6$ & $10.9 \pm 0.7$ \\
\hline
\end{tabular}

\section{Table 4}

Amount of platelets and thrombocyte indices in blood of rabbits consuming different amounts of I, Se, $\mathrm{S}(\mathrm{x} \pm \mathrm{SE}, \mathrm{n}=6)$

\begin{tabular}{|c|c|c|c|c|}
\hline \multirow{3}{*}{ Parameter } & \multirow{3}{*}{$\begin{array}{c}\text { Group } \\
\text { of } \\
\text { animals }\end{array}$} & \multicolumn{3}{|c|}{ Periods of the study } \\
\hline & & \multirow{2}{*}{$\begin{array}{l}\text { preparation, } \\
\text { 53rd day of life }\end{array}$} & \multicolumn{2}{|c|}{$\begin{array}{c}\text { experimental } \\
\text { (day of life/day of the study) }\end{array}$} \\
\hline & & & $68 / 15$ & $85 / 33$ \\
\hline \multirow{5}{*}{ PLT, $10^{9} / \mathrm{L}$} & $\mathrm{C}$ & $448 \pm 53$ & $663 \pm 68$ & $626 \pm 47$ \\
\hline & I & $426 \pm 56$ & $560 \pm 36$ & $562 \pm 56$ \\
\hline & II & $486 \pm 138$ & $789 \pm 137$ & $547 \pm 79$ \\
\hline & III & $493 \pm 127$ & $601 \pm 92$ & $552 \pm 59$ \\
\hline & IV & $483 \pm 39$ & $782 \pm 177$ & $557 \pm 46$ \\
\hline \multirow{5}{*}{ MPV, fL } & $\mathrm{C}$ & $5.65 \pm 0.11$ & $5.45 \pm 0.21$ & $5.38 \pm 0.20$ \\
\hline & I & $5.73 \pm 0.20$ & $5.46 \pm 0.18$ & $5.42 \pm 0.29$ \\
\hline & II & $5.38 \pm 0.37$ & $5.45 \pm 0.15$ & $5.32 \pm 0.35$ \\
\hline & III & $5.58 \pm 0.20$ & $5.50 \pm 0.29$ & $5.50 \pm 0.09$ \\
\hline & IV & $5.85 \pm 0.04$ & $5.42 \pm 0.20$ & $5.55 \pm 0.11$ \\
\hline \multirow{5}{*}{ PWD, \% } & $\mathrm{C}$ & $0.267 \pm 0.030$ & $0.369 \pm 0.040$ & $0.304 \pm 0.080$ \\
\hline & I & $0.245 \pm 0.031$ & $0.317 \pm 0.026$ & $0.315 \pm 0.045$ \\
\hline & II & $0.327 \pm 0.041$ & $0.431 \pm 0.071$ & $0.308 \pm 0.064$ \\
\hline & III & $0.273 \pm 0.130$ & $0.334 \pm 0.042$ & $0.302 \pm 0.031$ \\
\hline & IV & $0.284 \pm 0.028$ & $0.421 \pm 0.096$ & $0.368 \pm 0.068$ \\
\hline \multirow{5}{*}{ PCT, $\%$} & $\mathrm{C}$ & $16.0 \pm 0.4$ & $14.8 \pm 0.6$ & $14.7 \pm 0.5$ \\
\hline & I & $14.5 \pm 1.1$ & $14.7 \pm 0.9$ & $14.7 \pm 0.8$ \\
\hline & II & $14.7 \pm 1,0$ & $15.5 \pm 0.4$ & $14.7 \pm 0.6$ \\
\hline & III & $15.2 \pm 0.5$ & $14.9 \pm 0.8$ & $14.9 \pm 0.5$ \\
\hline & IV & $15.6 \pm 0.7$ & $14.8 \pm 0.8$ & $15.4 \pm 0.4$ \\
\hline
\end{tabular}

Content of albumin in the blood of rabbits of the experimental groups was not significant against the control, though there was seen a tendency towards higher level after consumption of a greater amount of the supplements used. The level of creatinine did not exceed physiological parameters and in the blood of rabbits of experimental groups II, III and IV was respectively 9.2\% $(\mathrm{P}<0.05), 15.0 \%(\mathrm{P}<0.01)$ and $15.4 \%(\mathrm{P}<0.001)$ higher on the 33rd day of the study compared with the control group (Table 6). Concentration of urea in blood of rabbits did not change significantly throughout the study, which may indicate insignificant impact of the additives used on activation of processes that are involved in changes in this parameter in the organism of rabbits. 
Table 5

Biochemical parameters of the organisms of rabbits consuming various amounts of $\mathrm{I}, \mathrm{Se}, \mathrm{S}(\mathrm{x} \pm \mathrm{SE}, \mathrm{n}=6)$

\begin{tabular}{|c|c|c|c|c|}
\hline \multirow{3}{*}{ Parametrs } & \multirow{3}{*}{$\begin{array}{l}\text { Group of } \\
\text { animals }\end{array}$} & \multicolumn{3}{|c|}{ Periods of the study } \\
\hline & & \multirow{2}{*}{$\begin{array}{l}\text { preparation, } \\
\text { 53rd day of life }\end{array}$} & \multicolumn{2}{|c|}{$\begin{array}{c}\text { experimental } \\
\text { (day of life/day of the study) }\end{array}$} \\
\hline & & & $68 / 15$ & $85 / 33$ \\
\hline \multirow{5}{*}{$\begin{array}{l}\text { Total protein, } \\
\mathrm{g} / \mathrm{L}\end{array}$} & $\mathrm{C}$ & $48.0 \pm 1.0$ & $53.1 \pm 1.8$ & $58.2 \pm 2.9$ \\
\hline & I & $47.2 \pm 0.8$ & $50.9 \pm 1.0$ & $60.9 \pm 1.9$ \\
\hline & II & $48.0 \pm 0.7$ & $49.6 \pm 0.6$ & $63.7 \pm 2.4$ \\
\hline & III & $48.0 \pm 1.0$ & $54.1 \pm 2.2$ & $66.8 \pm 0.4^{*}$ \\
\hline & IV & $44.1 \pm 2.4$ & $53.3 \pm 2.3$ & $63.2 \pm 1.4$ \\
\hline \multirow{5}{*}{$\begin{array}{l}\text { Aspartate } \\
\text { aminotransfe- } \\
\text { rase, U/L }\end{array}$} & $\mathrm{C}$ & $20.3 \pm 4.3$ & $17.7 \pm 1.4$ & $16.5 \pm 1.7$ \\
\hline & I & $19.0 \pm 1.7$ & $20.2 \pm 1.8$ & $16.4 \pm 1.9$ \\
\hline & II & $20.0 \pm 2.2$ & $18.4 \pm 0.9$ & $14.2 \pm 0.4$ \\
\hline & III & $17.4 \pm 2.3$ & $16.0 \pm 1.0$ & $24.6 \pm 3.7$ \\
\hline & IV & $19.3 \pm 1.8$ & $20.1 \pm 1.6$ & $20.8 \pm 2.9$ \\
\hline \multirow{5}{*}{$\begin{array}{l}\text { Alanine } \\
\text { aminotransfe- } \\
\text { rase, U/L }\end{array}$} & $\mathrm{C}$ & $52.4 \pm 7.4$ & $56.2 \pm 5.5$ & $68.4 \pm 7.2$ \\
\hline & I & $43.6 \pm 3.0$ & $59.6 \pm 2.7$ & $63.5 \pm 4,5$ \\
\hline & II & $53.8 \pm 7.5$ & $53.1 \pm 5.5$ & $58.0 \pm 3.6$ \\
\hline & III & $46.4 \pm 5.6$ & $58.8 \pm 4.3$ & $63.2 \pm 8.7$ \\
\hline & IV & $50.8 \pm 5.1$ & $45.9 \pm 3.3$ & $69.1 \pm 8.3$ \\
\hline \multirow{5}{*}{$\begin{array}{l}\text { Alkaline } \\
\text { phosphatase, } \\
\text { U/L }\end{array}$} & $\mathrm{C}$ & $452 \pm 33$ & $326 \pm 15$ & $378 \pm 20$ \\
\hline & I & $418 \pm 34$ & $412 \pm 61$ & $428 \pm 34$ \\
\hline & II & $485 \pm 38$ & $468 \pm 44^{*}$ & $405 \pm 56$ \\
\hline & III & $467 \pm 69$ & $473 \pm 31 * *$ & $399 \pm 17$ \\
\hline & IV & $459 \pm 33$ & $416 \pm 31 *$ & $383 \pm 33$ \\
\hline
\end{tabular}

Table 6

Some biochemical parameters of the blood of rabbits consumed various amounts of $\mathrm{I}, \mathrm{Se}, \mathrm{S}(\mathrm{x} \pm \mathrm{SE}, \mathrm{n}=6)$

\begin{tabular}{|c|c|c|c|c|}
\hline \multirow{3}{*}{ Parameters } & \multirow{3}{*}{ Group } & \multicolumn{3}{|c|}{ Period of study } \\
\hline & & \multirow{2}{*}{$\begin{array}{l}\text { preparation, } \\
53^{\text {rd }} \text { day of life }\end{array}$} & $\begin{array}{r}\mathrm{e} \\
\text { (age/day of con }\end{array}$ & experimental \\
\hline & & & $68 / 15$ & $85 / 33$ \\
\hline \multirow{5}{*}{$\begin{array}{l}\text { Albumins, } \\
\mathrm{g} / \mathrm{L}\end{array}$} & $\mathrm{C}$ & $30.9 \pm 1.1$ & $38.1 \pm 1.6$ & $37.1 \pm 3.0$ \\
\hline & I & $35.6 \pm 3.5$ & $40.8 \pm 1.4$ & $35.7 \pm 1.8$ \\
\hline & II & $31.1 \pm 1.8$ & $38.8 \pm 1.5$ & $40.3 \pm 3.7$ \\
\hline & III & $34.9 \pm 2.5$ & $37.8 \pm 1.4$ & $42.9 \pm 2.4$ \\
\hline & IV & $36.6 \pm 3.9$ & $40.6 \pm 1.8$ & $42.6 \pm 1.3$ \\
\hline \multirow{5}{*}{$\begin{array}{l}\text { Creatinine, } \\
\mu \mathrm{mol} / \mathrm{L}\end{array}$} & $\mathrm{C}$ & $79.6 \pm 2.2$ & $96.6 \pm 2.4$ & $96.9 \pm 2.2$ \\
\hline & I & $85.2 \pm 0.7$ & $104.8 \pm 3.4$ & $107.4 \pm 4.6$ \\
\hline & II & $100.2 \pm 11.3$ & $99.9 \pm 2.6$ & $105.9 \pm 2.4^{*}$ \\
\hline & III & $92.0 \pm 7.6$ & $103.3 \pm 2.8$ & $111.5 \pm 3.7^{* *}$ \\
\hline & IV & $82.6 \pm 0,9$ & $99.8 \pm 4.8$ & $111.9 \pm 0.8^{* * *}$ \\
\hline \multirow{5}{*}{$\begin{array}{l}\text { Urea, } \\
\mathrm{mmol} / \mathrm{L}\end{array}$} & $\mathrm{C}$ & $4.5 \pm 0.8$ & $6.8 \pm 0.4$ & $8.1 \pm 0.5$ \\
\hline & I & $4.1 \pm 0.4$ & $6.2 \pm 0.5$ & $7.8 \pm 0.5$ \\
\hline & II & $5.1 \pm 0.2$ & $6.7 \pm 0.4$ & $7.9 \pm 0.5$ \\
\hline & III & $4.9 \pm 0.3$ & $7.9 \pm 0.4$ & $7.7 \pm 0.6$ \\
\hline & IV & $5.0 \pm 0.1$ & $6.2 \pm 0.2$ & $8.6 \pm 1.0$ \\
\hline
\end{tabular}

Consumption of citrate compound of microelements by the rabbits for 33 days of the study positively influenced the parameters of lipid metabolism in young rabbits, as observed at the first stage of the study (Table 7). Therefore, content of triacylglicerols in the blood of rabbits of the experimental groups did not undergo significant changes throughout the study. At the same time, content of cholesterol in the blood of rabbits of experimental groups III and IV was significantly higher at the first stage of the study compared with the control group. This may indicate a selectively periodic impact that depends on the amount of the supplement used in the diet of young rabbits.

Consumption of various amounts of the compound by the rabbits caused changes in the level of calcium and phosphorus in the blood plasma of rabbits of the experimental groups compared with the control, which were within the physiological values (Table 8). Study of the content of total calcium and inorganic phosphorus in blood plasma revealed no significant changes in their levels. Nonetheless, their quantitative level was not as significant as the ratio of calcium to phosphorus, which is more physiologically significant in the organism of animals, and especially rabbits in the period after weaning.

Consumption of different amounts of the microelements by the animals of the experimental groups for 33 days of the study caused normali- zation of the ratio of calcium and phosphorus, which resulted in normalization of metabolism and reduced stress in the organism of rabbits.

Table 7

Content of triacylglycerols and cholesterol in the blood of rabbits consumed various amounts of $\mathrm{I}, \mathrm{Se}, \mathrm{S}(\mathrm{x} \pm \mathrm{SE}, \mathrm{n}=6)$

\begin{tabular}{|c|c|c|c|c|}
\hline \multirow{3}{*}{ Parameter } & \multirow{3}{*}{ Group } & \multicolumn{3}{|c|}{ Period of the study } \\
\hline & & \multirow{2}{*}{$\begin{array}{l}\text { preparation, } \\
53^{\text {rd }} \text { day of life }\end{array}$} & \multicolumn{2}{|c|}{$\begin{array}{c}\text { experimental (age/day } \\
\text { of consumption of the additives) }\end{array}$} \\
\hline & & & $68 / 15$ & $85 / 33$ \\
\hline \multirow{5}{*}{$\begin{array}{l}\text { Triacyl- } \\
\text { glycerol, } \\
\text { mmol/L }\end{array}$} & $\mathrm{C}$ & $1.01 \pm 0.13$ & $0.93 \pm 0.14$ & $0.77 \pm 0.27$ \\
\hline & I & $1.11 \pm 0.23$ & $0.87 \pm 0.13$ & $0.84 \pm 0.20$ \\
\hline & II & $1.10 \pm 0.22$ & $0.67 \pm 0.10$ & $0.82 \pm 0.10$ \\
\hline & III & $0.97 \pm 0.17$ & $1.08 \pm 0.30$ & $0.81 \pm 0.06$ \\
\hline & IV & $1.18 \pm 0.13$ & $0.91 \pm 0.07$ & $0.77 \pm 0.13$ \\
\hline \multirow{5}{*}{$\begin{array}{l}\text { Cholesterol, } \\
\mathrm{mmol} / \mathrm{L}\end{array}$} & $\mathrm{C}$ & $1.05 \pm 0.07$ & $1.13 \pm 0.21$ & $1.23 \pm 0.13$ \\
\hline & I & $1.35 \pm 0.18$ & $1.34 \pm 0.17$ & $1.09 \pm 0.12$ \\
\hline & II & $1.50 \pm 0.18^{*}$ & $1.64 \pm 0.27$ & $1.01 \pm 0.10$ \\
\hline & III & $1.02 \pm 0.12$ & $1.98 \pm 0.22 *$ & $1.38 \pm 0.15$ \\
\hline & IV & $1.03 \pm 0.12$ & $1.84 \pm 0.21 *$ & $1.37 \pm 0.24$ \\
\hline
\end{tabular}

Table 8

Content of total calcium and inorganic phosphorus and their ratio in the blood of rabbits consuming different amounts of $\mathrm{I}, \mathrm{Se}, \mathrm{S}(\mathrm{x} \pm \mathrm{SE}, \mathrm{n}=6)$

\begin{tabular}{lcccc}
\hline & & \multicolumn{3}{c}{ Periods of the study } \\
\cline { 3 - 5 } Parameters & Group & $\begin{array}{c}\text { preparation, } \\
\text { 53 }\end{array}$ & & \multicolumn{2}{c}{$\begin{array}{c}\text { experimental (age/day } \\
\text { of consumption of additives) }\end{array}$} \\
\cline { 3 - 5 } Total & C & $3.88 \pm 0.09$ & $2.28 \pm 0.06$ & $2.93 \pm 0.17$ \\
calcium, & I & $3.60 \pm 0.16$ & $2.28 \pm 0.07$ & $3.20 \pm 0.13$ \\
mmol/L & II & $3.95 \pm 0.13$ & $2.38 \pm 0.14$ & $3.10 \pm 0.14$ \\
& III & $3.50 \pm 0.15$ & $2.44 \pm 0.11$ & $2.98 \pm 0.06$ \\
& IV & $3.90 \pm 0.08$ & $2.47 \pm 0.20$ & $2.97 \pm 0.03$ \\
\hline & C & $2.00 \pm 0.00$ & $1.50 \pm 0.07$ & $1.80 \pm 0.19$ \\
phon-organic & I & $2.23 \pm 0.27$ & $1.58 \pm 0.08$ & $1.54 \pm 0.15$ \\
mmol/L & II & $2.05 \pm 0.10$ & $1.68 \pm 0.08$ & $1.54 \pm 0.18$ \\
& III & $1.83 \pm 0.13$ & $1.48 \pm 0.09$ & $1.62 \pm 0.10$ \\
& IV & $2.03 \pm 0.10$ & $1.57 \pm 0.14$ & $1.67 \pm 0.15$ \\
\hline
\end{tabular}

\section{Discussion}

Ingression of solution of microelements I, Se, $\mathrm{S}$ in nano amounts to young rabbits of meat breed caused impact on the liquid transport system blood. Blood function is related to the physiological action of separate constituents of plasma and formed elements. Particularly, the amount of leukocytes in the blood of rabbits of experimental group II was significantly lower, and in group III was higher on the 15th day of the study compared with the control. Consumption of the greatest amount of solution of microelements equaling $20.0 \mu \mathrm{g}$ of $\mathrm{I} / \mathrm{L}$ of water by animals of group IV led to significant increase in the number of white blood cells in the blood of the animals on the 31st day of the study compared with the control. In the organism of animals, function of lymphocytes is associated with the processes of immunogenesis, and monocytes and granulocytes belong to active phagocytes in the blood. The amounts of lymphocytes, monocytes and granulocytes throughout the study did not significantly change, though there was a tendency towards the levels within the physiological values. The obtained results demonstrating significant changes in the amount of white blood cells and their positive tendencies may indicate a more notable positive dose-dependent impact of the solution of citrates of $\mathrm{I}, \mathrm{Se}, \mathrm{S}$ microelements in nano amounts on non-specific factors of protection of the organism of young rabbits in a critical period of their ontogenesis - weaning. It should be noted that the consumption of physiologically reasoned amounts of zinc citrate caused positive changes in the number of white blood cells and the immune system in the organism of rabbits after weaning (Kisera et al., 2019; Lesyk et al., 2020). This may be explained by the specific effect of nano-sized microelements. In particular, increase in bioavailability may be achieved by improving solubility of biologically active substances in the digestive tract, their protection against the conditions of increased acidity and controlled release into the gastrointernal tract by improved transfer through the wall of the intestine, and the determining 
factors are the size of the particles, properties of the surface and physical condition of the nanomaterials used that influence the final nutritional value (Kozik et al., 2019).

It has to be noted that changes in white blood cells and their forms in the blood of rabbits under the action of I, Se, S were insignificant, except for the number of white blood cells. Different were the red blood parameters. Therefore, the amount of red blood cells in the blood of rabbits of experimental groups I, II and III was higher $(\mathrm{P}<0.05)$ at the first stage of the study (15th day) and higher in animals of experimental groups I, II; III and IV ( $\mathrm{P}<0.001-0.05)$ at the final stage of the study (33rd day) compared with the control group. The level of hemoglobin in the blood of animals of experimental groups II and III was higher $(\mathrm{P}<0.05)$ throughout the study, and in animals of group I significantly exceeded the control $(\mathrm{P}<0.05)$ on the 33rd day of the study. It has to be noted that the obtained data were confirmed by other studies of consumption of physiologically reasoned amounts of cisilium citrate in the organism of rabbits after weaning (Lesyk et al., 2020). The results of the study of the impact of solution of nano microelements may be related to peculiarities of functioning of the digestive tract, particularly digestion type, when the main metabolic processes are related to the impact of the microflora, therefore, the amount and bioavailibity of nutrients and needs to be taken into account with the action of microflora of the cecum, both positive and negative. Probiotics, prebiotics and synbiotics are able to inhibit the intestinal pathogenic microflora, because they can compete with positive microflora for places of adhesion, inhibiting growth of pathogens or stimulate, modulate and regulate immune response, initiating activation of specific genes inside and outside the digestive tracts. Moreover, it was also demonstrated that probiotics regulate accumulation of fat and stimulate angiogenesis of the intestine (Kerry et al., 2018).

Levels of hematocrit value at the final stage of the study in the blood of animals of experimental groups I-III were higher $(\mathrm{P}<0.001-0.05)$ compared with the control. This may indicate effect of the used supplements on hematopoietic function of the organism of rabbits, being more notable in conditions of dose-dependent use of citrates of microelements. Amount of formed elements in blood is an important parameter of physiological condition of animals and their provision with nutritive and mineral substances, because blood is the main transport system of the organism, which is the first to react to their deficiency or excess in diet. Microelements in nano sizes from 1 to $100 \mathrm{~nm}$ are able to exert biological effects on the organism. These peculiarities of nanosize may also change biological interaction, particularly the contact of nanoparticles with the surface of biological environment, which is important and affect the surface charge, form and may play a determining role in bioavailability, stability of the influence, deposition ability, interaction and penetration into cell of the organism (Glazer et al., 2011).

The indicated peculiarities of biological effect of microelements as nanoparticles caused changes in red blood cell indices in the red blood of the rabbits. Specifically, mean concentration of hemoglobin in red blood cells on the 15th day and red cell distribution width on the 33rd day of the study were higher $(\mathrm{P}<0.05)$ in the blood of animals of experimental group III. Despite the significant role of platelets in the organism of rabbits, there are very few studies of their functional condition in the period of active growth and development, which are available in the literature sources. The conducted studies determined no significant changes in platelets and their indices, though there were tendencial changes in platelets depending on the amount of applied microelements.

Blood parameters are quick markers of physiological condition of the animal status, especially rabbits characterized by low absorption of nutrients from the digestive tract. Deficiency of any nutrient, component of feed, including micro- or even ultramicroelement, negatively affects the functional abilities of the entire organism of rabbits. The results of the study of the effects of selenium as a nanocompound indicate that deficiency of selenium is associated with high degree of development of reactive oxygen species and protection of red blood cells and hemoglobin in red blood cells against free radicals and oxidative stress. This enzyme contains selenium, and therefore selenium indirectly takes part in prevention of oxidative impacts on red blood cells (Zheng et al., 2019). The studies revealed that adding Se at different levels had no effect on PCV, HB, $\mathrm{RBC}$ and $\mathrm{WBC}$, while significant differences $(\mathrm{P}<0.05)$ were observed in heterophiles and lymphocytes. Various sources of selenium had no effect on white blood cells, red blood cells, hematocrit and platelets in the blood of broiler chickens (Fawzy et al., 2016).

Use of various amounts of microlements in the diet of rabbits caused changes in biochemical parameters of the blood. Particularly, animals of experimental group III were observed to have higher content of total protein on the 33rd day of the study, compared with the control. Activities of ALT and AST was within the physiological values, but had no significant changes compared with the control, though the activity of alkaline phosphatase was higher in the blood of animals of experimental groups II, III and VI $(\mathrm{P}<0.01-0.05)$ on the 15th day of the study compared with the control group.

The literature sources report that providing the animals with optimum amount of microelement reduces stress that occurs in rabbits as a result of weaning from their mother and was studied perfectly in poultry farming (AbdEl-Hack et al., 2019; Darmohray et al., 2019). Selenium is included in the supplement and is a microelement necessary for animals. It displays numerous tendencies related to fertility and prevention of diseases (Boostani et al., 2015). Selenium controls the level of lipid peroxides and hydrogen peroxides formed as a result of regular metabolic activity. Bioavailibility of selenium is related to its physical form (Samak et al., 2018; Sobolev et al., 2020, 2021). With development of nanotechnology, selenium was obtained that has special characteristics: high surface and catalytic activities, large adsorbing surface and low toxicity, which is crucial to selenium (Abd-Allah \& Hashem, 2015).

Studies of other biochemical parameters revealed that the level of creatinine in the blood of rabbits of experimental groups II, III and IV was higher $(\mathrm{P}<0.001-0.05)$ on the 33rd day of the study compared with the control. This clearly demonstrates the physiological course of metabolic processes in the organism and absence of negative impact of the applied additives. The literature sources report that the end product of metabolism, creatin - creatinine is synthesized in these organs from aminoacids: arginin, glycin, metionine, accumulates in the kidneys.

Content of triacylglycerols in the blood of rabbits of the experimental group underwent no significant changes during the study, whereas content of cholesterol in the blood of rabbits of experimental groups III and IV was significantly higher on the 15th day of the study. Increase in the total concentration of cholesterol in the blood may be related to higher content of thyroxene, which promotes mobilization of cholesterol from the blood or the tissues or impact of the hydroxylase enzyme that takes part in transformation of cholesterol to uric acids in the liver of rabbits. Changes in biochemical effect were seen as a result of ingression of zinc citrate by rabbits, confirming possible changes caused by use of the compound in the form of salt and nano amounts.

Watering rabbits with various amounts of $\mathrm{I}, \mathrm{Se}, \mathrm{S}$ led to changes in levels of calcium and phosphorum in the blood plasma of rabbits.

Calcium in the organism of rabbits is absorbed from food, and its excesses are removed with urine. Much more complicated is the situation with phosphorus in the diet of rabbits. Mechanisms of digestion of phosphorus in the organism of rabbits are not completely clear. In most species of mammals, inorganic phosphorus is absorbed from the duodenum and the small intestine and regulated by the endocrine system. Research revealed the exsistence of active mechanism of transport of phosphorus from the duodenum and proximal small intestine in 3-month old rabbits. Quite likely, absorption of phosphorus is more active in young animals than adult ones. An important indicator of balanced diet of the animals, especially fast-growing young rabbits is the ratio of calcium and phosphorus in their organisms. Optimum proportion of calcium and phosphorus is considered to be within 1.5-2.0:1. Studies revealed that in the preparation period, on the 53rd day of life, the proportion of calcium and phosphorus in young rabbits was within 2.11:1 at the first stage of the study and 1.86:1 at the second stage of the study, indicating excess of calcium in the diet of animals and thus its increased content in the blood, which reduces digestibility of phosphorus in the organism. Nonetheless, use of various amounts of additives with microelements for 33 days of the study caused normalization of the ratio of calcium and phosphorus in animals of the experimental groups, being within the determined physiological parameters.

Thus, the obtained results of the study of hematologic and biochemical parameters of the blood of rabbits indicate dose-dependent effect of I, 
Se, S supplements on the organism of rabbits, which may indicate effectiveness of using nanocompounds of mineral substances in their diet.

\section{Conclusions}

Addition of solution of I, Se, S microelements to the diet of rabbits after weaning in the amounts of respectively $2.5,5.0,10.0$ and $20.0 \mu \mathrm{g}$ of $\mathrm{I} / \mathrm{L}$ of water led to its physiological impact on separate systems and organs of their organism, manifested in lower amount of white blood cells in the blood of animals that received the supplement in the amount of $5.0 \mu \mathrm{g}$ of $\mathrm{I} / \mathrm{L}$ and higher amount in the group of animals that received the supplement in the amount of 10.0 on the 15 th day and $20.0 \mu \mathrm{g}$ of $\mathrm{I} / \mathrm{L}$ of water on the 31st day of the study compared with the control. Absolute numbers of lymphocytes, monocytes and granulocytes did not change significantly during the period of the study, though their parameters were within the physiological values compared with the control. The number of red blood cells in the blood of rabbits of all experimental groups was higher during the study compared with the control group of animals. Concentration of hemoglobin in the blood of rabbits that consumed 5.0 and $10.0 \mu \mathrm{g} \mathrm{I/L}$ of water was significantly higher during the study. Hematocrit value in the blood of animals that received 2.5, 5.0 and $10.0 \mu \mathrm{g}$ of $\mathrm{I} / \mathrm{L}$ was significantly higher on the 33rd day of the study compared with the control. Ingression of solution of microelements in the amount of $10.0 \mu \mathrm{g}$ of $\mathrm{I} / \mathrm{L}$ of water led to higher content of total protein on the 33rd day of the study compared with the control group of animals. The level of creatinine did not exceed the physiological parameters in the blood of rabbits that consumed 5.0, 10.0 and 20.0 and was higher on the 33rd day of the study compared with the control group. Content of triacylglycerols in the blood of rabbits of the experimental groups underwent no changes throughout the study, whereas the content of cholesterol in the blood of rabbits that received 10.0 and $20.0 \mu \mathrm{g}$ of $\mathrm{I} / \mathrm{L}$ of water was significantly higher at the first stage of the study compared with the control group. Therefore, the conducted studies determined an indefinite impact of various amounts of the studied compound of biogenic elements on the organism of rabbits after weaning, which may indicate dose-dependent action of this supplement.

\section{References}

Abd El-Hack, M. E., Abdelnour, S. A., Taha, A. E., Khafaga, A. F., Arif, M., Ayasan, T., Swelum, A. A., Abukhalil, M. H., Alkahtani, S., \& Aleya, L. (2020). Herbs as thermoregulatory agents in poultry: An overview. Science of the Total Environment, 703, 134-399.

Abd-Allah, S., \& Hashem, K. S. (2015). Selenium nanoparticles increase the testicular antioxidant activity and spermatogenesis in male rats as compared to ordinary selenium. Journal of Analytical Science and Technology, 3(1), 792-802.

Abdel-Wareth, A. A. A., \& Metwally, A. E. (2020). Productive and physiological response of male rabbits to dietary supplementation with thyme essential oil. Animals, 10(10), 1844.

Abdel-Wareth, A. A. A., Taha, E. M., Südekum, K.-H., \& Lohakare, J. (2018). Thyme oil inclusion levels in a rabbit ration: Evaluation of productive performance, carcass criteria and meat quality under hot environmental conditions. Animal Nutrition, 4(4), 410-416.

Abouelezz, K. F. M., Abou-Hadied, M., Yuan, J., Elokil, A. A., Wang, G., Wang, S., Wang, J., \& Bian, G. (2019). Nutritional impacts of dietary oregano and Enviva essential oils on the performance, gut microbiota and blood biochemicals of growing ducks. Animal, 13, 2216-2222.

Boostani, A., Sadeghi, A., Mousavi, S., Chamani, M., \& Kashan, N. (2015). Effects of organic, inorganic, and nano-Se on growth performance, antioxidant capacity, cellular and humoral immune responses in broiler chickens exposed to oxidative stress. Livestock Science, 178, 330-336.

Darmohray, L. M., Luchyn, I. S., Gutyj, B. V., Golovach, P. I., Zhelavskyi, M. M., Paskevych, G. A., \& Vishchur, V. Y. (2019). Trace elements transformation in young rabbit muscles. Ukrainian Joumal of Ecology, 9(4), 616-621.

Dwyer, J. T., Wiemer, K. L., Dary, O., Keen, C. L., King, J. C., Miller, K. B., Philbert, M. A., Tarasuk, V., Taylor, C. L., \& Gaine, P. C. (2015). Fortification and health: Challenges and opportunities. Advances in Nutrition, 6(1), 124-131.

Fawzy, M. M., El-sadawi, H. A., \& El-dien, M. H. (2016). Hematological and biochemical performance of poultry following zinc oxide and sodium selenite supplementation as food additives. Annals of Clinical Pathology, 4(4), 1076.
Glazer, E. S., Zhu, C., Hamir, A. N., Borne, A., Thompson, C. S., \& Curley, S. A. (2011). Biodistribution and acute toxicity of naked gold nanoparticles in a rabbit hepatic tumor model. Nanotoxicology, 5(4), 459-468.

Kerry, R. G., Patra, J. K., Gouda, S., Park, Y., Shin, H. S., \& Das, G. (2018). Benefaction of probiotics for human health: A review. Journal of Food and Drug Analysis, 26(3), 927-939.

Kisera, Y. V., Storchak, Y. G., Gutyj, B. V., Bozhyk, L. Y., Magrelo, N., Sus, Y., Dashkovskyy, O., Pryimych, V. I., Vus, U., Kit, L., \& Sachuk, R. (2019). Structural and functional features of the vermiform appendix at the tissue and cellular levels in rabbits after the introduction of immunobiological drugs. Ukrainian Joumal of Ecology, 9(2), 217-226.

Kozik, V., Bak, A., Pentak, D., Hachula, B., Pytlakowska, K., Rojkiewicz, M., Jampilek, J., Sieron, K., Jazowiecka-Rakus, J., \& Sochanik, A. (2019). Derivatives of graphene oxide as potential drug carriers. Journal of Nanoscience and Nanotechnology, 19(5), 2489-2492.

Lesyk, Y., Ivanytska, A., Kovalchuk, I., Monastyrska, S., Hoivanovych, N., Gutyj, B., Zhelavskyi, M., Hulai, O., Midyk, S., Yakubchak, O., \& Poltavchenko, T. (2020). Hematological parameters and content of lipids in tissues of the organism of rabbit saccording to the silic on connection. Ukrainian Joumal of Ecology, 10(1), 15-22.

Reda, F. M., El-Saadony, M. T., Elnesr, S. S., Alagawany, M., \& Tufarelli, V. (2020). Effect of dietary supplementation of biological curcumin nanoparticles on growth and carcass traits, antioxidant status, immunity and caecal microbiota of Japanese quails. Animals, 10(5), 754.

Samak, D. H., El-Sayed, Y. S., Shaheen, H., El-Far, A., Swelum, A. A., Noreldin, A., El-Naggar, K., Abdelnour, S., Saied, E. M., El-Seedi, H. R. (2018). Developmental toxicity of carbon nanoparticles during embryogenesis in chicken. Environmental Science and Pollution Research, 27, 19058-19072.

Sheiha, A. M., Abdelnour, S. A., El-Hack, M. E. A., Khafaga, A. F., Metwally, K. A., Ajarem, J. S., Maodaa, S. N., Allam, A. A., \& El-Saadony, M. T. (2020). Effects of dietary biological or chemical-synthesized nano-selenium supplementation on growing rabbits exposed to thermal stress. Animal, 10(3), 430.

Shi, L. G., Xun, W. J., Yue, W. B., Zhang, C. X., Ren, Y. S., Liu, Q., Wang, Q., \& Shi, L. (2011). Effect of sodium selenite, Se-yeast and nano-elemental selenium on growth performance, Se concentration and antioxidant status in growing male goats. Small Ruminant Research, 96(1), 49-52.

Shulman, M. V., Pakhomov, O. Y., \& Brygadyrenko, V. V. (2017). Effect of lead and cadmium ions upon the pupariation and morphological changes in Calliphora vicina (Diptera, Calliphoridae). Folia Oecologica, 44(1), 28-37.

Sobolev, O. I., Gutyj, B. V., Sobolieva, S. V., Borshch, O. O., Kushnir, I. M., Petryshak, R. A., Naumyuk, O. S., Kushnir, V. I., Petryshak, O. Y., Zhelavskyi, M. M., Todoriuk, V. B., Sus, H. V., Levkivska, N. D., Vysotskij, A. O., \& Magrelo, N. V. (2020). Review of germanium environmental distribution, migrateon and accumulation. Ukrainian Journal of Ecology, 10(2), 200-208.

Sobolev, O. I., Gutyj, B. V., Sobolieva, S. V., Borshch, O. O., Nedashkivsky, V. M., Kachan, L. M., Karkach, P. M., Nedashkivska, N. V., Poroshinska, O. A., Stovbetska, L. S., Emelyanenko, A. A., Shmayun, S. S., \& Guta, Z. A. (2020). Selenium in natural environment and food chains. A review. Ukrainian Journal of Ecology, 10(4), 148-158.

Sobolev, O. I., Lisohurska, D. V., Pyvovar, P. V., Topolnytskyi, P. P., Gutyj, B. V., Sobolieva, S. V., Borshch, O. O., Liskovich, V. A., Verkholiuk, M. M., Petryszak, O. Y., Kuliaba, O. V., Golodiuk, I. P., Naumjuk, O. S., Petryszak, R. A., \& Dutka, H. I. (2021). Modeling the effect of different dose of selenium additives in compound feed on the efficiency of broiler chicken growth. Ukrainian Journal of Ecology, 11(2), 292-299.

Swelum, A. A., Elbestawy, A. R., El-Saadony, M. T., Hussein, E. O. S., Alhotan, R., Suliman, G. M., Taha, A. E., Ba-Awadh, H., El-Tarabily, K. A., \& Abd ElHack, M. E. (2021). Ways to minimize bacterial infections, with special reference to Escherichia coli, to cope with the first-week mortality in chicks: An updated overview. Poultry Science, 100(5), 101-139.

Vlislo, V. V. (2012). Laboratomi metody doslidzhen u biolohii, tvarynnytstvi ta veterynarnij medytsyni [Laboratory methods of research in biology, animal husbandry and veterinary medicine]. Spolom, Lviv (in Ukrainian).

Zazharska, N., Boyko, O., \& Brygadyrenko, V. (2018). Influence of diet on the productivity and characteristics of goat milk. Indian Joumal of Animal Research, 52(5), 711-717.

Zheng, S., Zhao, J., Xing, H., \& Xu, S. (2019). Oxidative stress, inflammation, and glycometabolism disorder-induced erythrocyte hemolysis in selenium-deficient exudative diathesis broilers. Joumal of Cellular Physiology, 234(9), 16328 16337. 